\title{
SERUM VITAMIN D LEVELS IN HEALTHY URBAN POPULATION AT REPRODUCTIVE AGE: EFFECTS OF AGE, GENDER AND SEASON
}

\author{
Meriç Karacan1, Akın Usta², Sermin Biçer', Gül Baktır', Gül İpek Gündogan¹, Ceyda Sancakli Usta², Gulsema \\ Akinci $^{3}$ \\ ${ }^{1}$ Department of Obstetrics and Gynaecology, School of Medicine, Yeni Yuzyil University, Istanbul, Turkey \\ 2Department of Obstetrics and Gynaecology, School of Medicine, Balikesir University, Balikesir, Turkey \\ ${ }^{3}$ Department of Internal Medicine, Balikesir Havran State Hospital, Balikesir, Turkey
}

\begin{abstract}
SUMMARY
Objective: The aim of the study was to determine the effects of age, gender and season on vitamin $\mathrm{D}$ status in healthy urban population at reproductive age. Also, we investigated the distribution of population into different groups regarding $25(\mathrm{OH}) \mathrm{D}$ levels.

Methods: Serum 25(OH)D levels of 21,317 participants: 5,364 men (25.1\%) and 15,953 women (74.8\%), aged between 18-45 years, applying to two medical centres for check-up located in the same city were retrospectively analyzed. Group I consisted of 14,720 participants (11,257 women and 3,463 men) in the first centre and Group II consisted of 6,597 participants (4,696 women and 1,901 men) in the second centre.

Results: The mean 25(OH)D levels did not differ between women and men in both groups: $23.4(S D=14.4)$ and $23.1(S D=12.6)$ in Group I, and $22.6(S D=15.9)$ and $23.1(S D=14.3)$ in Group II, respectively, $(p>0.05)$. Similar trends exhibiting lower mean 25(OH)D levels at younger ages and higher levels at later ages were observed in both groups; a seasonal variation of $25(\mathrm{OH}) \mathrm{D}$ levels was observed in both genders with the highest levels in August and September and the lowest levels from February through April; percentages of women with $25(\mathrm{OH}) \mathrm{D}$ level of $<5 \mathrm{ng} / \mathrm{ml}$ were significantly higher than of men in Group I ( $1.4 \%$ vs. $0.2 \%$, respectively, $p<0.001)$ and in Group II ( $4.1 \%$ vs. $1.1 \%$, respectively, $p<0.001)$.

Conclusion: There is a slight increase in serum $25(\mathrm{OH}) \mathrm{D}$ levels from 18 through 45 years of age in healthy population. The seasonal variation of $25(\mathrm{OH}) \mathrm{D}$ levels is prominent in both genders with men having slightly lower levels in some months of winter and higher levels in summer as compared to women. The prevalence of women having $25(\mathrm{OH}) \mathrm{D}$ levels less than $5 \mathrm{ng} / \mathrm{ml}$ is higher than that of men.
\end{abstract}

Key words: vitamin D, 25(OH)D level, age, season, gender

Address for correspondence: A. Usta, Department of Obstetrics and Gynaecology, Faculty of Medicine, Ballkesir University, Cagis Yerleskesi, Bigadic yolu, Balikesir, Turkey. E-mail:drakinusta@gmail.com

https://doi.org/10.21101/cejph.a5947

\section{INTRODUCTION}

Vitamin D, a pro-hormone, is an essential molecule for the maintenance of bone mineral density as its deficiency may lead to rickets in children and osteoporosis in the elderly (1). Vitamin $\mathrm{D}$ receptors have been identified in various tissues and organs, implicating the role of multiple functions. Vitamin D deficiency has also been linked to several clinical conditions such as diabetes mellitus, cardiovascular disease, autoimmune diseases, depression, infectious diseases, and cancer (2-4). However, the majority of these associations were found in observational studies rather than randomized clinical trials (5).

Exposure to sunlight (ultraviolet B with wavelength ranging between 290 and $315 \mathrm{~nm}$ ) stimulates vitamin D production from 7-dehydrocholesterol and constitutes up to $95 \%$ of vitamin $\mathrm{D}$, other sources being natural foods, fortified foods and supplements (6). Vitamin D is converted to 25 hydroxy vitamin D (25-OHD) in the liver and subsequently to the active form, 1,25 dihydroxyvitamin $\mathrm{D}(1,25-\mathrm{OH}-\mathrm{D})$ in the kidneys. Assessment of blood 25(OH)D is the accepted indicator of an individual's vita- min D status, having a half-life of 3 weeks. As 1,25-OH-D has a short half-life (4-6 hours) it does not provide a reliable marker for vitamin D status (7).

Serum 25(OH)D levels were found to be altered in different genders, women being more likely to have deficiency compared to men (8). This difference was attributed to more common outdoor activities of men and/or clothing habits of women (9).

Seasonal variation in $25(\mathrm{OH}) \mathrm{D}$ level depending on sun exposure was reported in the previous studies (10-13). A single 25(OH)D assessment provides information on current vitamin $\mathrm{D}$ status but does not reflect fluctuations which may occur throughout a year due to amount of sunshine received by the skin. There is a lack of data regarding the impact of seasonal variation of $25(\mathrm{OH}) \mathrm{D}$ levels on health.

Serum level of $25(\mathrm{OH}) \mathrm{D}$ pertaining to the amount of production may be affected by age, body mass index, physical activity, diet, duration of exposure to sunshine, time of exposure during the day, geographical location, skin surface, and skin type. The majority of circulating $25(\mathrm{OH}) \mathrm{D}$ and 1,25-dihydroxyvitamin D is firmly bound to vitamin $\mathrm{D}$ binding protein and albumin, with 
less than $1 \%$ circulating in an unbound form (2). Thus, factors affecting serum protein levels (e.g. acute infection) may mislead the interpretation of $25(\mathrm{OH}) \mathrm{D}$ levels (14). It can be argued that in some cases low 25(OH)D level may be a consequence of the presence of a clinical pathology rather than preceding it (15).

Circulating level of $25(\mathrm{OH}) \mathrm{D}$ is based on factors affecting skeletal integrity such as bone mineral density, parathyroid hormone (PTH), and intestinal calcium uptake (16). Optimal 25(OH)D level, considered to suppress PTH and provide maximal intestinal calcium absorption, was reported to be achieved between 9-38 $\mathrm{pg} / \mathrm{ml}$ (17). PTH begins to rise at $12-31.2 \mathrm{pg} / \mathrm{ml}$ meaning that 25(OH)D level should be maintained above this threshold (18).

Several cut-off values have been proposed to define insufficiency and deficiency of vitamin D status based on 25(OH)D levels by different societies (19). However, there is no universal consensus neither on "normal" values nor on values at which patients are recommended for vitamin $\mathrm{D}$ supplementation due to several confounding factors.

The aim of this retrospective study is to analyze serum $25(\mathrm{OH}) \mathrm{D}$ levels in a large healthy urban population not taking any vitamin D supplementation at reproductive age. The effects of age, gender and season were investigated, and the distribution of population according to the assigned cut-off values was expressed.

\section{MATERIALS AND METHODS}

\section{Subjects}

This study was designed to analyze $25(\mathrm{OH}) \mathrm{D}$ levels in healthy population in Istanbul, the largest urban agglomeration in Europe at latitude of $41^{\circ}$ north. February is the coldest month with an average temperature of $6{ }^{\circ} \mathrm{C}$ and the hottest is July at $24^{\circ} \mathrm{C}$ with 12 hours of sunshine. The effects of age, gender and each month on $25(\mathrm{OH}) \mathrm{D}$ levels were evaluated.

Serum 25(OH)D levels of 21.317 Caucasian participants, 15,953 women $(74.8 \%)$ and 5,364 men $(25.1 \%)$, were retrospectively analyzed. The range of age was between $18-45$ years with the mean $33.2(\mathrm{SD}=6.7)$ for women and $33.8(\mathrm{SD}=7.0)$ for men. Reproductive age was arbitrarily set at 45 years for women and men at corresponding ages were enrolled to provide homogeneity. Samples were taken between February 2014 and March 2018 from participants applying to two different medical centres for health check-up. Group I consisted of 14,720 participants (11,257 women and 3,463 men) admitted to the first centre and Group II consisted of 6,597 participants (4,696 women and 1,901 men) admitted to the second centre.

Excluded from the study were participants with hepatic, renal and gastrointestinal diseases, and hormonal disturbances such as thyroid and parathyroid dysfunctions. Participants who were taking vitamin D supplementation were also excluded. Only the first samples of participants were included. Participants were stratified according to 25(OH)D levels of 0-4.9, 5-9.9, 10-19.9, 20-29.9, $30-39.9,40-49.9$, and $\geq 50 \mathrm{ng} / \mathrm{ml}$ to determine the distribution of population into these groups. Results were expressed separately to compare the two centres using different $25(\mathrm{OH}) \mathrm{D}$ assays.

As various cut-off levels were recommended to define insufficiency, deficiency and severe deficiency in several studies and societies/organizations, these terms were not used to label partici- pants in the present study. The study was approved by the Ethics Committee of Istanbul Yeni Yuzyil University with registration number 1174/15.

\section{Assay of Vitamin D Level}

Blood samples $(5 \mathrm{ml})$ were collected through venipuncture of the cubital vein and centrifuged for 10 minutes after the collection, stored at $2-8{ }^{\circ} \mathrm{C}$ and analyzed within the same day. Levels of $25(\mathrm{OH}) \mathrm{D}$ were measured with enzyme-linked immunosorbent assay (ELISA, Euroimmun, Lübeck, Germany) in the first centre (Group I) and with liquid chromatography-tandem mass spectrometry assay (LC-MS/MS, Quest Diagnostics, Chantilly, VA, USA) in the second centre (Group II). The intra- and inter-assay coefficient of variation of ELISA were $4.9 \%$ and $7.8 \%$, respectively, and the lower detection limit was $2.4 \mathrm{ng} / \mathrm{ml}$. Intra- and inter-assay coefficient of variation was $7.5 \%$ and $10.7 \%$, respectively, and the lower detection limit was $4 \mathrm{ng} / \mathrm{ml}$ for LC-MS/MS assay. ELISA and LC-MS/MS showed high correlation $\left(\mathrm{r}^{2}=0.93\right)$.

\section{Statistical Analysis}

The levels of $25(\mathrm{OH}) \mathrm{D}$ were plotted at each age between 18 and 45 years for both genders. Normally distributed data were described as mean and standard deviation (SD). Distributions of continuous variables were determined by Kolmogorov-Smirnov test. The Levene test or F test was used for the evaluation of homogeneity of variances. The student's t test was used to compare normally distributed measurements for independent samples. The Chi-square test was used to compare categorical data. Correlation analysis was used to determine the association between age and $25(\mathrm{OH}) \mathrm{D}$ vitamin levels. Regression analysis was used to determine the relevant factors affecting the $25(\mathrm{OH}) \mathrm{D}$ vitamin levels. A p-value of $<0.05$ was considered statistically significant. The MedCalc Statistical Software Program version 17.2 (MedCalc, Belgium) was used for statistical analysis.

\section{RESULTS}

The average age of women and men were $33.3(\mathrm{SD}=6.6)$ and $33.9(\mathrm{SD}=7.0)$ in Group I, and $33.1(\mathrm{SD}=6.8)$ and 33.7 $(\mathrm{SD}=7.1)$ years in Group II, respectively. The mean 25(OH)D levels did not differ between women and men in both groups: $23.4 \mathrm{ng} / \mathrm{ml}(\mathrm{SD}=14.4)$ and $23.1 \mathrm{ng} / \mathrm{ml}(\mathrm{SD}=12.6)$ in Group I, and $22.6 \mathrm{ng} / \mathrm{ml}(\mathrm{SD}=15.9)$ and $23.1 \mathrm{ng} / \mathrm{ml}(\mathrm{SD}=14.3)$ in Group II, respectively $(\mathrm{p}>0.05)$.

The mean 25(OH)D levels corresponding to each age for women and men from 18 through 45 years for Group I and Group II are shown in Figure 1 and Figure 2, respectively. A similar trend exhibiting lower levels at younger ages and higher levels at later ages were observed in both groups. Of note, the 25(OH)D levels in men aged 18-25 years in Group I and 20-25 years in Group II were higher than those detected in women at the same age.

The mean 25(OH)D level at each month was determined in the two groups. In Group I, the lowest mean level was detected in April and the highest mean level in August: $17.8 \mathrm{ng} / \mathrm{ml}(\mathrm{SD}=13.5)$ and $28.4 \mathrm{ng} / \mathrm{ml}(\mathrm{SD}=12.3)$, respectively $(\mathrm{p}<0.001)$. Men had significantly lower mean 25(OH)D levels in March and April: 


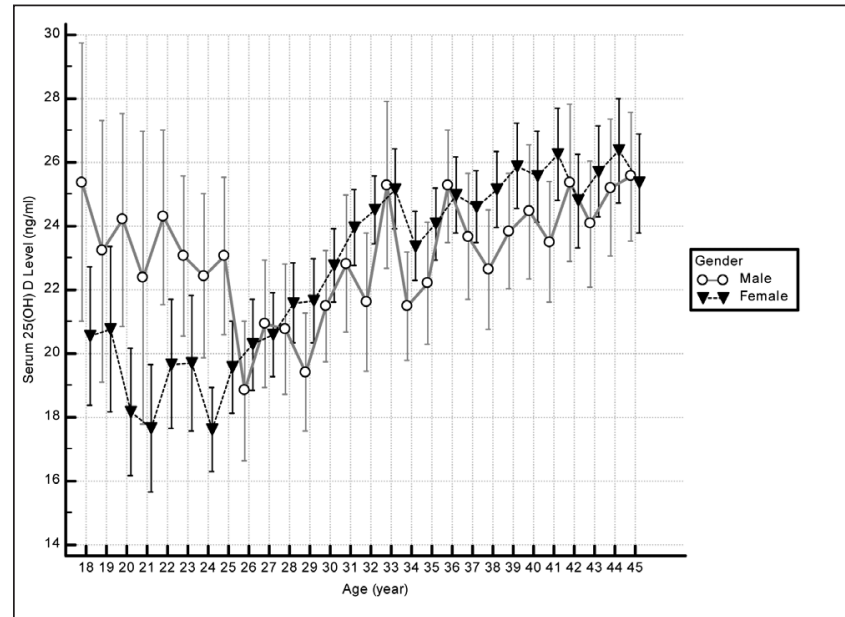

Fig. 1. Mean serum 25(OH)D levels of men and women at different ages in Group I.

Points: mean 25(OH)D value; Bars: 95\% confidence intervals for mean

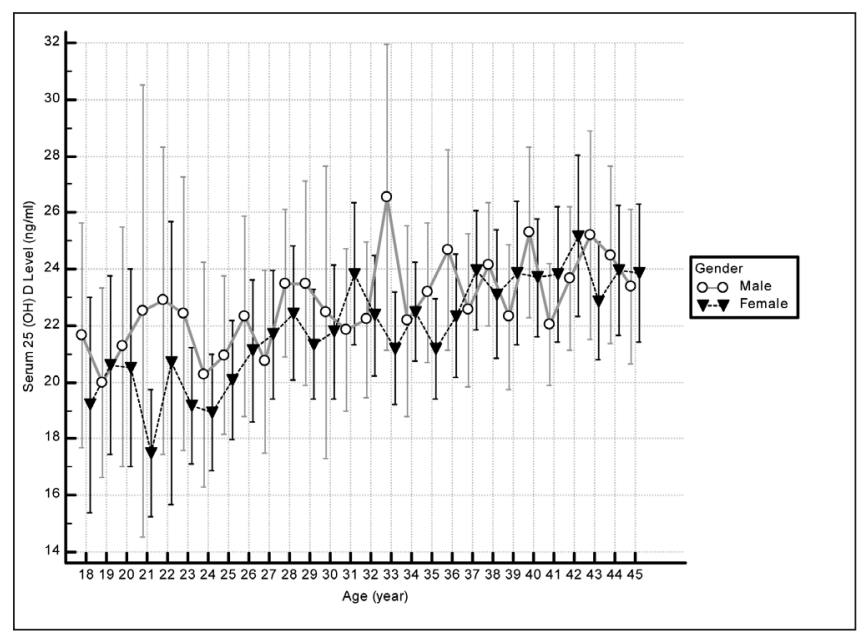

Fig. 2. Mean serum 25(OH)D levels of men and women at different ages in Group II.

Points: mean 25(OH)D value; Bars: $95 \%$ confidence intervals for mean

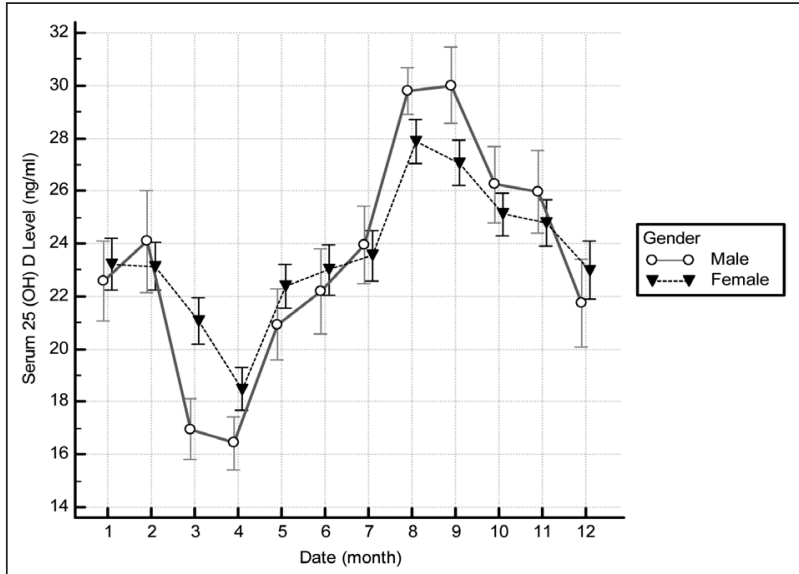

Fig. 3. Monthly changes in mean 25(OH)D levels of men and women in Group I.

Points: mean $25(\mathrm{OH})$ D value; Bars: $95 \%$ confidence intervals for mean

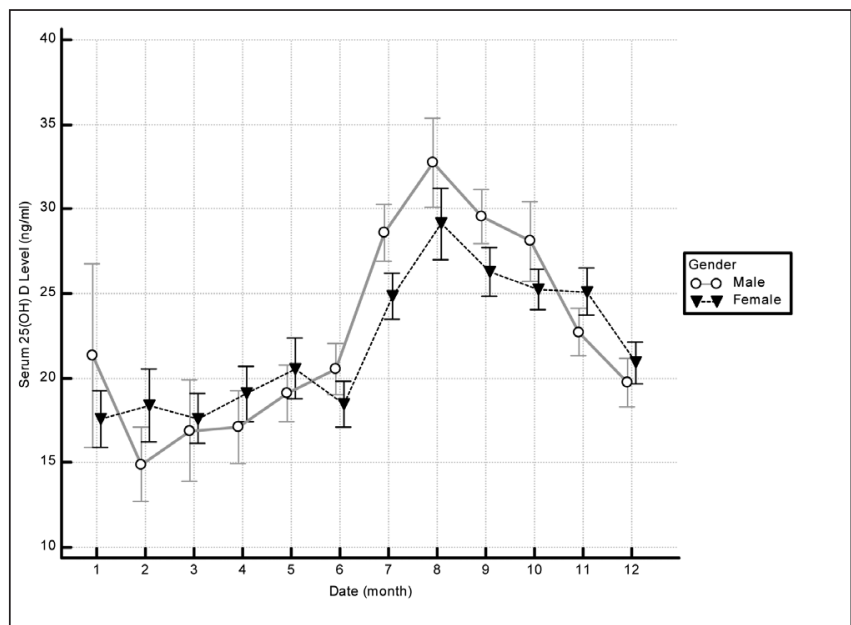

Fig. 4. Monthly changes in mean $25(\mathrm{OH}) \mathrm{D}$ levels of men and women in Group II.

Points: mean 25(OH)D value; Bars: 95\% confidence intervals for mean

Table 1. Mean serum 25(OH)D levels detected in different months in Group I $(N=14,720)$

\begin{tabular}{|c|c|c|c|c|c|}
\hline \multirow[b]{2}{*}{ Month } & \multirow[b]{2}{*}{$\mathrm{n}$} & \multicolumn{3}{|c|}{ Serum 25(OH)D (ng/ml) } & \multirow[b]{2}{*}{$p$-value } \\
\hline & & $\begin{array}{l}\text { All subjects } \\
\text { Mean (SD) }\end{array}$ & $\begin{array}{c}\text { Females } \\
\text { Mean (SD) }\end{array}$ & $\begin{array}{c}\text { Males } \\
\text { Mean (SD) }\end{array}$ & \\
\hline January & 1,147 & $23.1(14.3)$ & $23.2(14.7)$ & $22.6(12.6)$ & 0.471 \\
\hline February & 1,199 & $23.3(14.7)$ & $23.1(14.5)$ & $24.1(15.5)$ & 0.340 \\
\hline March & 1,510 & $20.1(14.6)$ & $21.1(15.4)$ & $16.9(11.2)$ & $<0.001$ \\
\hline April & 1,623 & $17.8(13.5)$ & $18.4(14.3)$ & $16.4(11.2)$ & 0.002 \\
\hline May & 1,328 & $22.1(13.4)$ & $22.3(13.9)$ & $20.9(11.5)$ & 0.071 \\
\hline June & 1,083 & $22.8(13.9)$ & $23.1(14.3)$ & $22.2(12.3)$ & 0.395 \\
\hline July & 1,180 & $23.6(14.4)$ & $23.5(15.1)$ & $23.9(11.6)$ & 0.647 \\
\hline August & 1,405 & $28.4(12.3)$ & $27.8(13.4)$ & $29.8(9.3)$ & 0.002 \\
\hline September & 1,247 & $27.6(13.3)$ & $27.1(13.6)$ & $30.1(11.8)$ & $<0.001$ \\
\hline October & 1,219 & $25.3(12.7)$ & $25.1(12.9)$ & $26.2(12.1)$ & 0.203 \\
\hline November & 970 & $25.1(12.2)$ & $24.7(12.4)$ & $25.9(11.8)$ & 0.210 \\
\hline December & 809 & $22.7(13.3)$ & $22.9(13.8)$ & $21.7(11.5)$ & 0.217 \\
\hline
\end{tabular}


Table 2. Mean serum 25(OH)D levels detected in different months in Group II $(N=6,597)$

\begin{tabular}{|c|c|c|c|c|c|}
\hline \multirow[b]{2}{*}{ Month } & \multirow[b]{2}{*}{$\mathrm{n}$} & \multicolumn{3}{|c|}{ Serum 25(OH)D (ng/ml) } & \multirow[b]{2}{*}{$\mathrm{p}$-value } \\
\hline & & $\begin{array}{c}\text { All subjects } \\
\text { Mean (SD) }\end{array}$ & $\begin{array}{l}\text { Females } \\
\text { Mean (SD) }\end{array}$ & $\begin{array}{c}\text { Males } \\
\text { Mean (SD) }\end{array}$ & \\
\hline January & 305 & $18.4(16.1)$ & $17.5(13.1)$ & $21.3(22.9)$ & 0.189 \\
\hline February & 311 & $17.4(15.1)$ & $18.3(16.5)$ & $14.9(10.1)$ & 0.026 \\
\hline March & 500 & $17.3(15.3)$ & $17.5(14.3)$ & $16.7(17.9)$ & 0.666 \\
\hline April & 537 & $18.5(15.6)$ & $19.1(16.4)$ & $17.1(12.8)$ & 0.154 \\
\hline May & 548 & $20.1(16.4)$ & $20.5(18.2)$ & $19.1(10.5)$ & 0.246 \\
\hline June & 479 & $19.1(11.6)$ & $18.4(12.4)$ & $20.5(9.4)$ & 0.044 \\
\hline July & 569 & $25.9(13.1)$ & $24.8(13.5)$ & $28.6(11.5)$ & $<0.001$ \\
\hline August & 452 & $30.3(18.1)$ & $29.1(18.8)$ & $32.7(16.4)$ & 0.046 \\
\hline September & 582 & $27.2(13.7)$ & $26.2(14.7)$ & $29.5(10.9)$ & 0.003 \\
\hline October & 714 & $25.9(14.5)$ & $25.2(14.1)$ & $28.1(15.8)$ & 0.035 \\
\hline November & 816 & $24.4(15.7)$ & $25.1(17.3)$ & $22.7(10.9)$ & 0.018 \\
\hline December & 784 & $20.5(13.8)$ & $20.9(14.7)$ & $19.7(11.4)$ & 0.222 \\
\hline
\end{tabular}

Table 3. Distribution of serum according to different ranges of $25(\mathrm{OH}) \mathrm{D}$ level in Group I $(N=14,720)$

\begin{tabular}{|l|c|c|c|}
\hline $\begin{array}{l}\text { Serum } \\
\mathbf{2 5}(\mathbf{O H}) \mathbf{D}(\mathrm{ng} / \mathrm{ml})\end{array}$ & $\begin{array}{c}\text { All subjects } \\
\mathbf{n}(\%)\end{array}$ & $\begin{array}{c}\text { Females } \\
\mathbf{n}(\%)\end{array}$ & $\begin{array}{c}\text { Males } \\
\mathbf{n}(\%)\end{array}$ \\
\hline $0-4.9$ & $170(1.2)$ & $162(1.4)$ & $8(0.2)$ \\
\hline $5-9.9$ & $2,196(14.9)$ & $1,778(15.8)$ & $418(12.1)$ \\
\hline $10-19.9$ & $4,485(30.5)$ & $3,282(29.2)$ & $1,203(34.7)$ \\
\hline $20-29.9$ & $3,822(26.0)$ & $2,874(25.5)$ & $948(27.4)$ \\
\hline $30-39.9$ & $2,366(16.1)$ & $1,816(16.1)$ & $550(15.9)$ \\
\hline $40-49.9$ & $1,011(6.8)$ & $793(7.0)$ & $218(6.3)$ \\
\hline$\geq 50$ & $670(4.5)$ & $552(4.9)$ & $118(3.4)$ \\
\hline Total & $14,720(100.0)$ & $11,257(76.5)$ & $3,463(23.5)$ \\
\hline
\end{tabular}

Table 4. Distribution of serum according to different ranges of $25(\mathrm{OH}) \mathrm{D}$ level in Group II $(\mathrm{N}=6,597)$

Table 4. Distribution of serum according to different ranges of 25(OH)D level in Group /I $(N=6,597)$
\begin{tabular}{|l|c|c|c|}
\hline $\begin{array}{l}\text { Serum } \\
\text { 25(OH)D (ng/ml) }\end{array}$ & $\begin{array}{c}\text { All subjects } \\
\mathrm{n}(\%)\end{array}$ & $\begin{array}{c}\text { Females } \\
\mathrm{n}(\%)\end{array}$ & $\begin{array}{c}\text { Males } \\
\mathrm{n}(\%)\end{array}$ \\
\hline $0-4.9$ & $210(3.2)$ & $190(4.0)$ & $20(1.1)$ \\
\hline $5-9.9$ & $944(14.3)$ & $755(16.1)$ & $190(10.0)$ \\
\hline $10-19.9$ & $2,207(33.5)$ & $1,503(32.0)$ & $706(37.1)$ \\
\hline $20-29.9$ & $1,722(26.1)$ & $1,162(24.7)$ & $563(29.6)$ \\
\hline $30-39.9$ & $892(13.5)$ & $617(13.1)$ & $276(14.5)$ \\
\hline $40-49.9$ & $326(5.0)$ & $238(5.1)$ & $89(4.7)$ \\
\hline$\geq 50$ & $288(4.4)$ & $231(4.9)$ & $57(3.0)$ \\
\hline Total & $6,597(100.0)$ & $4,696(71.2)$ & $1,901(28.8)$ \\
\hline
\end{tabular}

$16.9 \mathrm{ng} / \mathrm{ml}(\mathrm{SD}=11.2)$ vs. $21.1 \mathrm{ng} / \mathrm{ml}(\mathrm{SD}=15.4)$ and $16.4 \mathrm{ng} / \mathrm{ml}$ $(\mathrm{SD}=11.2)$ vs. $18.4 \mathrm{ng} / \mathrm{ml}(\mathrm{SD}=14.3)$, respectively, and higher levels in August and September: $29.8 \mathrm{ng} / \mathrm{ml}(\mathrm{SD}=9.3) \mathrm{vs} .27 .8 \mathrm{ng} /$ $\mathrm{ml}(\mathrm{SD}=13.4)$ and $30.1 \mathrm{ng} / \mathrm{ml}(\mathrm{SD}=11.8)$ vs. $27.1 \mathrm{ng} / \mathrm{ml}(\mathrm{SD}=$ $13.6 \mathrm{ng} / \mathrm{ml})$, respectively $(\mathrm{p}<0.001)$ than women (Table 1, Fig. 3).

Similarly, in Group II, lowest mean level was detected in March and highest level in August: $17.3 \mathrm{ng} / \mathrm{ml}(\mathrm{SD}=15.3) \mathrm{vs} .30 .3 \mathrm{ng} / \mathrm{ml}$ $(\mathrm{SD}=18.1)$, respectively $(\mathrm{p}<0.001)$. Men had significantly lower
25(OH)D level in February: $14.9 \mathrm{ng} / \mathrm{ml}(\mathrm{SD}=10.1)$ vs. $18.3 \mathrm{ng} /$ $\mathrm{ml}(\mathrm{SD}=16.5)$, respectively $(\mathrm{p}<0.05)$ but higher levels from June through October than women $(\mathrm{p}<0.05)$ (Table 2, Fig. 4). Levels did not differ between the genders in other months. Two parallel month-distribution curves for women and men were found in both groups, suggesting the role of sunshine on vitamin D formation.

Men had a larger variation in the mean 25(OH)D levels than women, having $83.5 \%$ and $119 \%$ increase from the month with 
Table 5. Variables affecting 25(OH)D levels in Group I and Group II

\begin{tabular}{|l|c|c|c|c|c|c|c|c|}
\hline \multirow{3}{*}{ Independent variables } & \multicolumn{9}{|c|}{ Serum 25(OH)D (ng/ml) } \\
\cline { 2 - 10 } & \multicolumn{4}{|c|}{ Group I } & \multicolumn{4}{c|}{ Group II } \\
\cline { 2 - 10 } & Coefficient & OR & $95 \%$ Cl & p-value & Coefficient & OR & $95 \%$ Cl & p-value \\
\hline Patients' gender & 0.0450 & 1.0461 & $0.9676-1.1309$ & 0.257 & 0.1369 & 0.9720 & $0.8821-1.0723$ & 0.094 \\
\hline Patients' age & 0.0375 & 1.0383 & $1.0332-1.0434$ & $<0.001$ & 0.1623 & 1.0182 & $1.0114-1.0251$ & $<0.001$ \\
\hline Blood sample collection month & 0.0996 & 1.1048 & $1.0936-1.1161$ & $<0.001$ & 0,1135 & 1.1203 & $1.1038-1.1370$ & $<0.001$ \\
\hline
\end{tabular}

Regression analysis; OR - odds ratio; $\mathrm{Cl}$ - confidence interval

the lowest level to that with the highest level in Group I and Group II, respectively. These results confirm the high variations throughout the year, apparently owing to the amount of sunshine. Variations in 25(OH)D levels of women between the lowest and highest months were $51 \%$ and $66.2 \%$ in Group I and Group II, respectively.

Percentages of participants corresponding to different groups are presented in Table 3 for Group I and in Table 4 for Group II. In Group I, $1.2 \%$ of participants had 25(OH)D level below $5 \mathrm{ng} /$ $\mathrm{ml}, 16.1 \%$ below $10 \mathrm{ng} / \mathrm{ml}, 46.6 \%$ below $20 \mathrm{ng} / \mathrm{ml}$, and $4.5 \%$ had $\geq 50 \mathrm{ng} / \mathrm{ml}$. Percentages corresponding to different groups were similar between men and women in both groups. In Group II, $3.2 \%$ of participants had $25(\mathrm{OH}) \mathrm{D}$ level below $5 \mathrm{ng} / \mathrm{ml}, 17.5 \%$ below $10 \mathrm{ng} / \mathrm{ml}, 51 \%$ below $20 \mathrm{ng} / \mathrm{ml}$, and $4.4 \% \mathrm{had} \geq 50 \mathrm{ng} / \mathrm{ml}$.

Percentage of women with $25(\mathrm{OH}) \mathrm{D}$ level of $<5 \mathrm{ng} / \mathrm{ml}$ was significantly higher than that of men in Group I ( $1.4 \%$ vs. $0.2 \%$, respectively, $p<0.001)$. Similarly, percentages of women with level of $<5 \mathrm{ng} / \mathrm{ml}$ and of $5-9.9 \mathrm{ng} / \mathrm{ml}$ were significantly higher than men in Group II (4.0\% vs. $1.1 \%$ and $16.1 \%$ vs. $10.0 \%$, respectively, $\mathrm{p}<0.001)$.

The correlation analysis showed that there was a weak correlation between the age of participants and the 25(OH)D levels $(\mathrm{r}=0.1120, \mathrm{p}<0.001)$

Regression analysis showed that patients' age and blood sample collection month affected the $25(\mathrm{OH}) \mathrm{D}$ values in Group I and Group II ( $p<0.001$ and $p<0.001$, respectively). However, there was no association between patients' gender and $25(\mathrm{OH}) \mathrm{D}$ values in Group I and Group II ( $p=0.2573$ and $p=0.0937$, respectively) (Table 5).

\section{DISCUSSION}

Several confounding factors have impact on serum vitamin D level and should be taken into consideration. In the present study, it has been shown that age, gender and season have substantial effects on serum $25(\mathrm{OH}) \mathrm{D}$ level and should be taken into account in the interpretation of results. The data represents a valid estimate of urban population as single assessment of 21,317 participants was analyzed.

The mean level of $25(\mathrm{OH}) \mathrm{D}$ tended to be higher as age increased from 18 to 45 years and this finding was consistent in two different groups. However, there was a weak correlation between age and 25(OH)D levels. A low-normal 25(OH)D level and high-normal parathormone were found during puberty so as to maintain greater bone size and mass in the presence of adequate calcium intake (20). It might be the reason of rise in
25(OH)D level throughout the years. Maggio et al. reported that age-associated fall of serum $25(\mathrm{OH}) \mathrm{D}$ starts earlier (around 50 years of age) in women than in men (around 70 years of age) (21). Jorde et al. examined the longitudinal changes in serum $25(\mathrm{OH}) \mathrm{D}$ levels throughout the years within same individuals and found that participants younger than 65 years had $0.8 \mathrm{ng} / \mathrm{ml}$ increase and those older than 65 years had $0.1 \mathrm{ng} / \mathrm{ml}$ decrease during the fourteen years of follow up (22).

Men were found to have higher levels of $25(\mathrm{OH}) \mathrm{D}$ than women in some studies $(8,23)$, but other studies did not reach the same conclusion (24). Although vitamin D binding protein levels and/or body fat content were hypothesized to be related to the differences in vitamin D levels across genders, these hypotheses were not confirmed (25). Arabi et al. reported that age but not gender modulates correlation between vitamin $\mathrm{D}$ and parathyroid hormone (26). In the present study, the mean serum 25(OH)D levels were similar between women and men aged $18-45$ years in both groups. However, very low levels of 25(OH)D $(<5 \mathrm{ng} /$ $\mathrm{ml})$ were more commonly detected in women as compared to men $(1.4 \%$ vs. $0.2 \%$ and $4.0 \%$ vs. $1.1 \%$ in Group I and Group II, respectively). It can be assumed that lifestyle (i.e., clothing, spending more time at home, restricted physical activity) rather than biological factors may be responsible for the high incidence of severely diminished 25(OH)D levels in women. Guzel et al. reported that veiled women had significantly lower mean $25(\mathrm{OH}) \mathrm{D}$ level than that of unveiled women (27). In another study, Buyukuslu et al. reported that $55 \%$ of the covered and $20 \%$ of uncovered female students were found to have $25(\mathrm{OH}) \mathrm{D}$ levels $<20 \mathrm{ng} / \mathrm{ml}$ (9).

It was found that $25(\mathrm{OH}) \mathrm{D}$ levels significantly fluctuated throughout the year in the present study. The lowest levels were found in spring and the highest levels in the end of summer. Notably, seasonal variation in $25(\mathrm{OH}) \mathrm{D}$ levels was more prominent in men than in women, almost doubling between the lowest and highest levels. Although, the mean 25(OH)D levels were higher in women just before summer, they were lower in the months with abundant sunshine compared to men, implicating more vigorous outdoor activities of men. Similar to the present study, Katrinaki et al. reported premenopausal females ( $\leq 50$ years) and corresponding males exhibited two parallel month-distribution curves of 25(OH)D levels, being nadir in April and highest in August (10). Cinar et al. found mean serum 25(OH)D level higher in summer than that in winter: $28.4 \mathrm{ng} / \mathrm{ml}(\mathrm{SD}=10.4)$ vs. 13.8 $\mathrm{ng} / \mathrm{ml}(\mathrm{SD}=6.6)$, respectively (13). Cigerli et al. found that mean 25(OH)D levels obtained in summer: $18.6 \mathrm{ng} / \mathrm{ml}(\mathrm{SD}=11.1)$ and autumn: $23.3 \mathrm{ng} / \mathrm{ml}(\mathrm{SD}=3.6)$ were significantly higher than levels in spring: $16.1 \mathrm{ng} / \mathrm{ml}(\mathrm{SD}=10.3)$ and winter: $14.6 \mathrm{ng} / \mathrm{ml}$ 
$(\mathrm{SD}=10.2)$ in the same city as the present study was performed (12). In a large Hungarian study, in accordance with our findings the lowest serum 25(OH)D level was found in March (13.5 \pm 4.2 $\mathrm{ng} / \mathrm{ml})$ and the highest in September $(24.1 \pm 6.1 \mathrm{ng} / \mathrm{ml})(\mathrm{p}<0.001)$ (23). Levels exhibited similar trends in both genders. The seasonal variation was also demonstrated in subjects taking vitamin D supplements (7).

Serum 25(OH)D levels exhibited a seasonal change of 4.8 $\mathrm{ng} / \mathrm{ml}$ in participants aged 55-65 years (11). An increase of $1.6 \mathrm{ng} / \mathrm{ml}$ in the level of $25(\mathrm{OH}) \mathrm{D}$ in persons aged $55-65$ years and a decrease of $1.6 \mathrm{ng} / \mathrm{ml}$ in those aged $65-88$ years were noted in the same study, suggesting that seasonal variation was more remarkable than the decline by age. Level of $25(\mathrm{OH}) \mathrm{D}$ obtained in winter was found to be correlated with the level in summer among Danish adolescent girls and elderly women (28). They reported that in order to achieve a level of $20 \mathrm{ng} / \mathrm{ml}$ in winter, a summer 25(OH)D level should be around $50 \mathrm{ng} / \mathrm{ml}$. As the importance of seasonal variation in body health remains unknown, the time of the year of the assessment of $25(\mathrm{OH}) \mathrm{D}$ level should always be taken into account to interpret the result.

Cut-off points for the definition of vitamin D status based on serum 25(OH)D have been reported by different societies (19). The cut-off value for $25(\mathrm{OH}) \mathrm{D}$ level can be established either by the consequences of deficiency - if any - or through the use of reference values within a specific population. Consensus regarding cut-off values for bone health as well as other healthcare measures has not been unequivocally settled. Severe vitamin D deficiency leading to overt skeletal abnormalities namely rickets/ osteomalacia has been set at $10 \mathrm{ng} / \mathrm{ml}$ (29). Below this level, substrate concentration to form dihydroxy metabolite may not be maintained sufficiently despite secondary hyperparathyroidism. On the other hand, rickets was reported to be associated with considerably lower 25(OH)D level, generally less than $5 \mathrm{ng} / \mathrm{ml}$ (4). In another study, histological osteomalacia was found in patients with $<25 \mathrm{ng} / \mathrm{ml}$ of $25(\mathrm{OH}) \mathrm{D}$, albeit some patients with very low values of $25(\mathrm{OH}) \mathrm{D}$ did not have evidence of osteomalacia (30). Besides, level of $25(\mathrm{OH}) \mathrm{D}$ may be within normal limit if rickets ensues from calcium deficiency, which makes a single assessment unreliable.

It was demonstrated that intestinal calcium absorption did not decline until 25(OH)D level dropped to $\leq 4 \mathrm{ng} / \mathrm{ml}$ (29). Low $25(\mathrm{OH}) \mathrm{D}$ does not always indicate the increased level of PTH and levels greater than $30 \mathrm{ng} / \mathrm{ml}$ does not guarantee PTH suppression (31). Supplementation of vitamin D may be relevant in a subgroup of patients with severe deficiency but the benefit in patients with the level of $<20 \mathrm{ng} / \mathrm{ml}$ without any clinical sign has yet to be solved (15).

Vitamin D levels ranged from 11 to $71 \mathrm{ng} / \mathrm{ml}$ in surfers exposed to sun at least 15 hours per week, implicating the high degree of individual variation (16). In a meta-analysis relating vitamin D to 137 different outcomes, it was stated that although association was found between maternal vitamin D status or supplementation and birth weight, convincing evidence of the role of vitamin D was lacking for other outcomes (32). It was recently reported that white patients with $25(\mathrm{OH}) \mathrm{D}$ levels of less than $20 \mathrm{ng} / \mathrm{ml}$ had greater all-cause mortality than those with levels between 20 and $50 \mathrm{ng} / \mathrm{ml}$ (33). However, it is not clear whether the low vitamin D levels is the consequence of the disease or causing it. Katrinaki et al. concluded that a cut-off level of 25(OH)D close to $20 \mathrm{ng} / \mathrm{ml}$ might better reflect the physiology of Mediterranean population (10). In the present study, almost half of the healthy participants had 25(OH)D levels $<20 \mathrm{ng} / \mathrm{ml}$.

Upper limit of 25(OH)D level was reported between $62-80$ $\mathrm{ng} / \mathrm{ml}$ in individuals exposed to abundant amount of sunshine, suggesting that cutaneous production seems to be suppressed over these limits (34). In our study, $4.5 \%$ of total population ( $4.6 \%$ in the first group and $4.4 \%$ in the second group) exhibited $25(\mathrm{OH}) \mathrm{D}$ level $\geq 50 \mathrm{ng} / \mathrm{ml}$ and no participant had a level over $80 \mathrm{ng} / \mathrm{ml}$. Increased risks at higher $25(\mathrm{OH}) \mathrm{D}$ levels were reported in some studies such as acute coronary syndrome (35), detrimental effect on spermatozoa and embryos (36), total cancer mortality in men (37). Hence, it appears plausible to consider the side effects of high vitamin D level prior to starting supplementation according to a single assessment of $25(\mathrm{OH}) \mathrm{D}$ level.

Vitamin D production is substantially dependent on ultraviolet B exposure, which decreases for higher degrees of the latitude, particularly above $37^{\circ}$ north, Istanbul is located at $41^{\circ}$ north, receiving adequate amount of sunshine throughout the year (9). Variation of $25(\mathrm{OH}) \mathrm{D}$ levels by month was found similar to our findings on a population living at $44^{\circ}$ north (23).

A number of methods have been developed to measure circulating $25(\mathrm{OH}) \mathrm{D}$, e.g., competitive protein-binding assay (CPBA), radioimmunoassay (RIA), high performance liquid chromatography (HPLC), and liquid chromatography coupled with mass spectrometry (LC/MS). Discrepancies between methods and laboratories range from $10 \%$ to $20 \%$, causing misinterpretation of the results (5). Additionally, all quantitative assessments may suffer from human, methodological and instrumental limitations which may cause inaccurate results. In the present study, two different assays were used in the two different groups of participants and the distribution of participants into different groups were found to be similar.

Although this study presents the data of a remarkable number of participants living in a highly populated city there are some limitations such as the lack of detailed demographic characteristics and bone mass of the population, number of hours exposed to sunshine per week, and clothing habits of women. However, a large number of participants enabled us to evaluate the effects of gender, each age between 18 and 45, and months on 25(OH)D levels. The findings of the present study provide clinicians with information on the noticeable impact of age and season as well as the distribution of healthy population in different ranges of 25(OH)D level.

\section{CONCLUSION}

There is a slight increase in serum 25(OH)D levels from 18 through 45 years of age in healthy population. Seasonal variation of $25(\mathrm{OH}) \mathrm{D}$ levels is prominent in both genders with men having slightly lower levels in some months of winter and higher levels in summer as compared to women. The prevalence of women having 25(OH)D levels less than $5 \mathrm{ng} / \mathrm{ml}$ is higher than that of men.

\section{Conflict of Interests}

None declared 


\section{REFERENCES}

1. Holick MF. Vitamin D deficiency. N Engl J Med. 2007;357(3):266-81.

2. Binkley N, Ramamurthy R, Krueger D. Low vitamin D status: definition, prevalence, consequences, and correction. Endocrinol Metab Clin North Am. 2010;39(2):287-301.

3. Stechschulte SA, Kirsner RS, Federman DG. Vitamin D: bone and beyond, rationale and recommendations for supplementation. Am J Med. 2009;122(9):793-802.

4. Thacher TD, Clarke BL. Vitamin D insufficiency. Mayo Clin Proc. 2011;86(1):50-60.

5. Taylor CL, Thomas PR, Aloia JF, Millard PS, Rosen CJ. Questions about vitamin D for primary care practice: input from an NIH Conference. Am J Med. 2015;128(11):1167-70.

6. Cesari M, Incalzi RA, Zamboni V, Pahor M. Vitamin D hormone: a multitude of actions potentially influencing the physical function decline in older persons. Geriatr Gerontol Int. 2011;11(2):133-42.

7. Holick MF. Vitamin D status: measurement, interpretation, and clinical application. Ann Epidemiol. 2009;19(2):73-8.

8. Wei Q, Chen Z, Tan X, Su H, Chen X, He W, et al. Relation of age, sex and bone mineral density to serum 25-hydroxyvitamin D levels in Chinese women and men. Orthop Surg. 2015;7(4):343-9.

9. Buyukuslu N, Esin K, Hizli H, Sunal N, Yigit P, Garipagaoglu M. Clothing preference affects vitamin D status of young women. Nutr Res. 2014;34(8):688-93.

10. Katrinaki M, Kampa M, Margioris A, Castanas E, Malliaraki N. Vitamin D levels in a large Mediterranean cohort: reconsidering normal cut-off values. Horm Athens Greece. 2016;15(2):205-23.

11. van Schoor NM, Knol DL, Deeg DJH, Peters FPAMN, Heijboer AC, Lips P. Longitudinal changes and seasonal variations in serum 25-hydroxyvitamin D levels in different age groups: results of the Longitudinal Aging Study Amsterdam. Osteoporos Int. 2014;25(5):1483-91.

12. Cigerli O, Parildar H, Unal AD, Tarcin O, Erdal R, Guvener Demirag N. Vitamin D deficiency is a problem for adult out-patients? A university hospital sample in Istanbul, Turkey. Public Health Nutr. 2013;16(7):130613.

13. Cinar N, Harmanci A, Yildiz BO, Bayraktar M. Vitamin D status and seasonal changes in plasma concentrations of 25-hydroxyvitamin D in office workers in Ankara, Turkey. Eur J Intern Med. 2014;25(2):197-201.

14. Jassil NK, Sharma A, Bikle D, Wang X. Vitamin D binding protein and 25-hydroxyvitamin D levels: emerging clinical applications. Endocr Pract. 2017;23(5):605-13

15. Lucas R, Neale R. What is the optimal level of vitamin D? - separating the evidence from the rhetoric. Aust Fam Physician. 2014;43(3):119-22.

16. Hollis BW, Wagner CL, Drezner MK, Binkley NC. Circulating vitamin D3 and 25-hydroxyvitamin D in humans: an important tool to define adequate nutritional vitamin D status. J Steroid Biochem Mol Biol. 2007;103(3-5):631-4.

17. Bischoff-Ferrari HA, Giovannucci E, Willett WC, Dietrich T, DawsonHughes B. Estimation of optimal serum concentrations of 25-hydroxyvitamin D for multiple health outcomes. Am J Clin Nutr. 2006;84(1):18-28.

18. Lips P. Which circulating level of 25-hydroxyvitamin D is appropriate? J Steroid Biochem Mol Biol. 2004;89-90(1-5):611-4.

19. Saggese G, Vierucci F, Prodam F, Cardinale F, Cetin I, Chiappini E, et al. Vitamin D in pediatric age: consensus of the Italian Pediatric Society and the Italian Society of Preventive and Social Pediatrics, jointly with the Italian Federation of Pediatricians. Ital J Pediatr. 2018;44(1):51. doi: 10.1186/s13052-018-0488-7.

20. Tylavsky FA, Ryder KM, Li R, Park V, Womack C, Norwood J, et al. Preliminary findings: 25(OH)D levels and PTH are indicators of rapid bone accrual in pubertal children. J Am Coll Nutr. 2007;26(5):462-70.

21. Maggio D, Cherubini A, Lauretani F, Russo RC, Bartali B, Pierandrei $\mathrm{M}$, et al. 25(OH)D Serum levels decline with age earlier in women than in men and less efficiently prevent compensatory hyperparathyroidism in older adults. J Gerontol A Biol Sci Med Sci. 2005;60(11):1414-9.
22. Jorde R, Sneve M, Hutchinson M, Emaus N, Figenschau Y, Grimnes G. Tracking of serum 25-hydroxyvitamin D levels during 14 years in a population-based study and during 12 months in an intervention study. Am J Epidemiol. 2010;171(8):903-8.

23. Niculescu DA, Capatina CAM, Dusceac R, Caragheorgheopol A, Ghemigian A, Poiana C. Seasonal variation of serum vitamin D levels in Romania. Arch Osteoporos. 2017;12(1):113. doi: 10.1007/s11657-0170407-3.

24. AlQuaiz AM, Kazi A, Fouda M, Alyousefi N. Age and gender differences in the prevalence and correlates of vitamin D deficiency. Arch Osteoporos. 2018;13(1):49. doi: 10.1007/s11657-018-0461-5.

25. Bolland MJ, Grey AB, Ames RW, Horne AM, Mason BH, Wattie DJ, et al. Age-, gender-, and weight-related effects on levels of 25-hydroxyvitamin $\mathrm{D}$ are not mediated by vitamin D binding protein. Clin Endocrinol (Oxf). 2007;67(2):259-64.

26. Arabi A, Baddoura R, El-Rassi R, El-Hajj Fuleihan G. Age but not gender modulates the relationship between PTH and vitamin D. Bone. 2010;47(2):408-12.

27. Guzel R, Kozanoglu E, Guler-Uysal F, Soyupak S, Sarpel T. Vitamin D status and bone mineral density of veiled and unveiled Turkish women. J Womens Health Gend Based Med. 2001;10(8):765-70.

28. Andersen R, Brot C, Jakobsen J, Mejborn H, Mølgaard C, Skovgaard LT, et al. Seasonal changes in vitamin D status among Danish adolescent girls and elderly women: the influence of sun exposure and vitamin D intake. Eur J Clin Nutr. 2013;67(3):270-4.

29. Need AG, O'Loughlin PD, Morris HA, Coates PS, Horowitz M, Nordin BEC. Vitamin D metabolites and calcium absorption in severe vitamin D deficiency. J Bone Miner Res. 2008;23(11):1859-63.

30. Priemel M, von Domarus C, Klatte TO, Kessler S, Schlie J, Meier S, et al. Bone mineralization defects and vitamin D deficiency: histomorphometric analysis of iliac crest bone biopsies and circulating 25-hydroxyvitamin D in 675 patients. J Bone Miner Res. 2010;25(2):305-12.

31. Chapuy MC, Preziosi P, Maamer M, Arnaud S, Galan P, Hercberg S, et al. Prevalence of vitamin D insufficiency in an adult normal population. Osteoporos Int. 1997;7(5):439-43.

32. Theodoratou E, Tzoulaki I, Zgaga L, Ioannidis JPA. Vitamin D and multiple health outcomes: umbrella review of systematic reviews and meta-analyses of observational studies and randomised trials. BMJ. 2014;348:g2035. doi: 10.1136/bmj.g2035.

33. Dudenkov DV, Mara KC, Petterson TM, Maxson JA, Thacher TD. Serum 25-hydroxyvitamin D values and risk of all-cause and causespecific mortality: a population-based cohort study. Mayo Clin Proc. 2018;93(6):721-30.

34. Barger-Lux MJ, Heaney RP. Effects of above average summer sun exposure on serum 25-hydroxyvitamin D and calcium absorption. J Clin Endocrinol Metab. 2002;87(11):4952-6.

35. Dror Y, Giveon SM, Hoshen M, Feldhamer I, Balicer RD, Feldman BS. Vitamin D levels for preventing acute coronary syndrome and mortality: evidence of a nonlinear association. J Clin Endocrinol Metab. 2013;98(5):2160-7.

36. Laganà AS, Vitale SG, Ban Frangež H, Vrtačnik-Bokal E, D’Anna R. Vitamin D in human reproduction: the more, the better? An evidence-based critical appraisal. Eur Rev Med Pharmacol Sci. 2017;21(18):4243-51.

37. Freedman DM, Looker AC, Abnet CC, Linet MS, Graubard BI. Serum 25-hydroxyvitamin D and cancer mortality in the NHANES III study (1988-2006). Cancer Res. 2010;70(21):8587-97.

Received September 9, 2019 Accepted in revised form November 13, 2020 